\title{
Impacts of the CSR strategies of technology companies on performance and competitiveness
}

\author{
Impacto de la estrategia de RSC en el desempeño y la competitividad de empresas tecnológicas
}

\author{
Juan Andrés Bernal-Conesa \\ Centro Universitario de la Defensa de San Javier (CUD), Santiago de la Ribera (Murcia), Spain \\ jandres.bernal@cud.upct.es
}

Antonio Juan Briones-Peñalver

Universidad Politécnica de Cartagena (UPCT), Facultad de Ciencias de la Empresa, Calle Real, Cartagena, Spain aj.briones@upct.es

Carmen de Nieves-Nieto

Universidad Politécnica de Cartagena (UPCT), Facultad de Ciencias de la Empresa, Cartagena, Spain carmen.denieves@upct.es

\begin{abstract}
This study used structural equation modelling to analyse and investigate the adoption of corporate social responsibility (CSR) strategies by the Spanish technology industry and the impacts of these strategies on technology companies' performance and competitiveness. The research was conducted using a survey of companies located in Spanish science and technology parks. The analyses' results reveal positive, direct and statistically significant relationships between companies' CSR strategies and competitiveness and between their competitiveness and performance. In addition, the results show that competitiveness is a mediating variable in the relationship between CSR strategies and technology companies' performance.
\end{abstract}

Keywords: Corporate social responsibility, technological company, competitiveness, performance.

\section{RESUMEN}

En este artículo se propone un modelo de ecuaciones estructurales para estudiar la adopción de una estrategia empresarial basada en la Responsabilidad Social Corporativa (RSC) en la industria tecnológica española y cómo dicha estrategia puede influir sobre la competitividad y el desempeño económico (performance). El estudio se llevó a cabo en empresas ubicadas en Parques Científicos y Tecnológicos españoles mediante una encuesta. Los resultados del modelo revelan que existe una relación positiva, directa y estadísticamente significativa entre la estrategia de RSC y la competitividad y entre ésta última y el performance. Además, se establece que la competitividad es una variable mediadora en la relación entre la estrategia de RSC y el Performance de la empresa tecnológica.

Palabras clave: Responsabilidad Social Corporativa, empresas tecnológicas, competitividad, performance.

\section{Introduction}

Business environments in recent years have been characterised by an acute economic crisis, which can be attributed not just to a change in economic cycles but also to the absence of values and ethical principles in the functioning of organisations (Melé, Argandoña, \& Sanchez-Runde, 2011). Therefore, one way to end the crisis could be through social innovation (Goldsmith, 2010) and corporate social responsibility (CSR). The latter is considered an innovation in company management that can help firms achieve maximum strategic value in all their functions. Some organisations even believe that CSR has protected them against the negative effects of the current economic crisis (Janssen, Sen, \& Bhattacharya, 2015). As a result, the traditional scope of CSR research has expanded to include frameworks for effective economic crisis management (Pérez \& Bosque, 2012).Effective CSR management can help organisations minimise the negative impacts of the crisis (Pérez-Ruiz \& Rodríguez-del-Bosque, 2012) and generate positive changes in business management in the search for success, improved reputations and competitive advantages (Gallardo-Vázquez \& Sánchez-Hernández, 2013).

The concept of CSR is not new as it was first used in the last century, originating in the United States (Gjølberg, 2009). Ever since then, companies have been facing a growing demand for social commitment from different stakeholders. The relationship between CSR and corporate performance has been widely studied, with researchers reporting contrasting results (Marín, Rubio, \& de Maya, 2012). Some studies show a positive relationship, whereas others show a negative relationship, with results also dependent on the time involved (Muñoz, Pablo, \& Peña, 2015).

Organisations now need to adapt constantly to economic changes in order to have a greater chance of survival in the market. Key factors in this process are innovation and competitiveness. In the last two decades, the debate about the strategic potential of CSR and the possible relationship between CSR and competitiveness has thus become increasingly relevant (Battaglia, Testa, Bianchi, Iraldo, \& Frey, 2014; Porter \& Kramer, 2006). Much has already been written about how a strategic adoption of CSR could lead to long-term financial rewards (Lee, 2008).

Competitiveness is a multidimensional concept that refers to the capacity to create sustainable competitive advantages that can be used both at the national and company levels (Vilanova, Lozano, \& Arenas, 2009). CSR has clearly become an important factor for the competitiveness of companies (Turyakira, Venter, \& Smith, 2014) since numerous studies have confirmed the 
positive relationship between social and economic performance (Lee, 2008). Thus, the effect of CSR on competitive success can include obtaining positive results for companies in terms of market positioning that extend beyond the financial sphere (Gallardo-Vázquez \& Sánchez-Hernández, 2013). This impact is stronger in sectors that are highly competitive (e.g. the technology sector) and that follow a proactive versus reactive strategy (Marín et al., 2012) versus CSR's effect in uncompetitive sectors, in which traditional advantages are brand, price, quality and distribution (Rives \& Bañón, 2008).

Currently, a growing number of Spanish companies believe that they must contribute to sustainable development by planning operations that foster economic growth and increase productivity and competitiveness while ensuring environmental protection. These firms also seek to promote social responsibility (Prado-Lorenzo, Gallego-Álvarez, García-Sánchez, \& RodríguezDomínguez, 2008) since investment in CSR initiatives can be a source of competitive advantages (Apospori, Zografos, \& Magrizos, 2012). These strategies are a way to improve the economic performance of companies (Hur, Kim, \& Woo, 2014).

Given this context, the aims of this study were to analyse (1) the influence of CSR strategies on economic performance, (2) the impacts of CSR strategieson the competitiveness of technology companies and (3) the direct influence of CSR on competitiveness and economic performance.

\section{Literature review}

In academic settings, CSR is often used as a comprehensive concept that describes a variety of issues relating to the responsibilities of businesses (Hillenbrand, Money, \& Ghobadian, 2013). CSR has no universally accepted definition (Dahlsrud, 2008) although CSR can be said to include not only strict compliance with existing legal obligations but also voluntary implementation of governance and management strategies, policies and procedures, as well as social, labour and environmental concerns and respect for human rights. CSR arises from organisations' relationships and transparent dialogues with stakeholders, in which organisations take responsibility for the consequences and impacts of their actions (Mendoza, de Nieves, \& Briones, 2010).

Some studies have shown that the implementation of CSR in organisationshas a positive relationship with financial benefits (Lo, 2010; Hammann, Habisch, \& Pechlaner, 2009) and, more specifically, that technological industries can increase their economic performance through CSR (Chang, 2009). Although no clear consensus has been reached in the debate on the impact of CSR measures on economic performance (Ramos, Manzanares, \& Gómez, 2014), most researchers suggest that a positive relationship should exist between the two variables (Gallardo-Vázquez \& Sanchez-Hernandez, 2014; Garcia-Castro, Ariño, \& Canela, 2009). However, some studies also claim the relationship is negative (Muñoz et al., 2015). As of yet, very few studies have examined the relationship between the CSR of technology companies and their performance (Wang, Chen, Yu \& Hsiao, 2015). Therefore, the following hypothesis was proposed in the present research:

\section{H1: CSR strategies have a positive impact on the performance} of technology companies.

Given the above findings, companies need to adopt formalised CSR practices and, thus,implement CSR procedures and tools that are aligned with their corporate strategies (Bocquet, Le Bas, Mothe, \& Poussing, 2013). Some studies suggest that CSR makes a significant positive contribution to national competitiveness and even levels of quality of life (Boulouta \& Pitelis, 2014). In other words, CSR is expected to translate into greater competitive success (Herrera, Larrán, \& Martínez-Martínez, 2013). As Vilanova et al. (2009) suggest, when CSR is integrated into business processes, it generates innovative practices and, therefore, improved competitiveness.

A large part of the CSR literature has, therefore, focused on the impact of CSR on firms' level of competitiveness (Boulouta \& Pitelis, 2014), including large and small companies and different sectors (Battaglia et al., 2014; Vidales \& Ortiz, 2014). More extensive research is needed on CSR's impact on Spanish technological companies to confirm in this specific context what previous research has shown, namely, that organisations that maintain a strategic orientation towards innovation and bet on improving their internal organisational capacities are more competitive in a globalised environment (Suñe, Bravo, Mundet, \& Herrera, 2012). To foster product and process innovations, companies must adopt formalised CSR practices as these make a positive contribution to competitiveness (Boulouta \& Pitelis, 2014). The second research hypothesis in the present study was proposed in the following terms:

H2: CSR strategies have a positive impact on the competitiveness of technology companies.

The relationship between performance and competitiveness has been observed in diverse studies of business strategies. Ranging from (Porter \& Kramer, 2006) work to the theory of resources and capabilities (Spanos \& Lioukas, 2001), a variety of research has related performance to competitiveness (Gallardo-Vázquez \& Sánchez-Hernández, 2014). Therefore, to complete the research hypotheses of the present study and develop the conceptual model, the third and last hypothesis was formulated as follows:

H3: A clear link exists between the competitiveness and performance of technological companies.

The hypotheses are summarised in the conceptual research model in Figure 1. 
Figure 1 - Conceptual research model

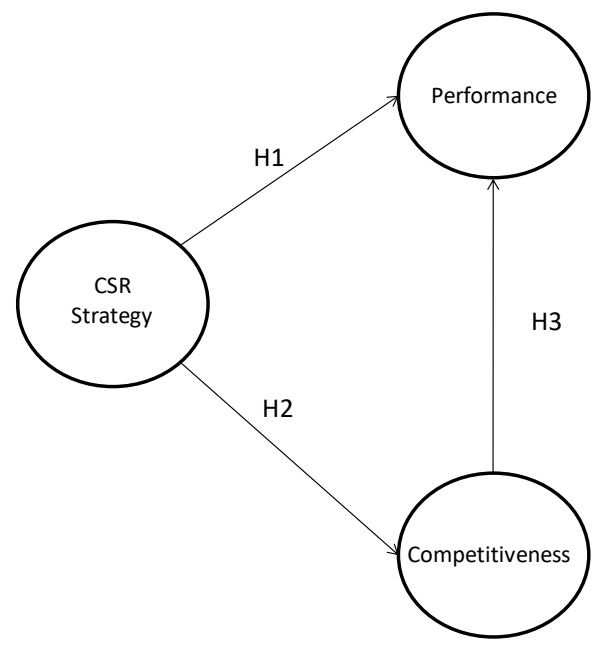

Source: Authors.

\section{Methodology}

This study focused on the technological sector since, according to Ketchen et al. (1997), the above conceptual model could contribute to a better understanding and explanation of organisational results if the research concentrated on a sample from a single industry or sector. For this reason, technological companies located in Spanish science and technology parks were selected as the sample. These parks have in common that they attract either newly created technological companies or already consolidated companies that foster regional development through a technological approach, as well as creating jobs and well-being (Jimenez-Zarco, Cerdan-Chiscano, \& Torrent-Sellens, 2013). Currently, there are 6,452 companies in the Asociación de Parques Científicos y Tecnológicos de España, which have created 151,562 jobs and, in 2014, generated a total turnover of $22,327,000$ euros.

To prepare for this study's analysis of the relationships between the constructs shown in Figure 1, a specific questionnaire was designed using a Likert-typefive-point scale (i.e. 1 = 'totally disagree' and 5 ='strongly agree'). This approach was selected because many questions referred to issues that cannot be quantified with a specific value (e.g. 'The organisation's management is involved in the implementation of CSR strategies.'). In general, the questionnaire included items related to CSR strategies, competitiveness and performance in line with surveys in other studies (Venter, Turyakira, \& Smith, 2014; Gallardo-Vázquez \& Sánchez-Hernández, 2013; Prajogo, Tang, \& Lai, 2012).

To ensure the results were empirically sound, an online survey was conducted. The final sampling method consisted of a nonprobability convenience sampling procedure. In other words, the sample consisted of units that facilitated measurement and that were accessible or favourable to participation (Miquel, Bigné, Cuenca, Miquel, \& Lévy, 1997). However, of the 489 companies consulted by telephone that initially were in favour of responding to the questionnaire, only 98 completed questionnaires during 2014, of which 56 were considered valid for this study, since only these 56 companies had implemented
CSR measures - or intended to do so - as a business strategy. The study population was the 489 companies contacted, so the final sample represented a valid response rate of $11.45 \%$ (error 12.35\%; $p=q=0.5$; confidence level $95 \% ; z=1.96$ ).

Following Henseler et al.'s (2014) advice, we used partial least squares (PLS) as this is a remarkably effective statistical tool in research on the management of organisations. Several previous studies have indicated that the required sample size is between 30 and 100 cases if the conceptual model has at least 3 or 4 indicators per construct (Roldán \& Sánchez-Franco, 2012). Moreover, a Monte Carlo simulation by Chin and Newsted (1999) showed that PLS can collect significant information from samples as small as 20 (Reinartz, Haenlein, \& Henseler, 2009). Therefore, our sample was considered sufficiently large enough to carry out a statistical analysis using structural equationmodelling (SEM) based on PLS.

\section{Results}

SEM was used to perform the analysis as SEM is a statistical procedure used to test the validity of functional, predictive and causal hypotheses. This multivariate statistical technique must be masteredin order to understand many fields of research and to conduct basic or applied research in behavioural, managerial, health and social sciences (Bagozzi \& Yi, 2011).

The technique chosen within SEM was PLS using SmartPLS 2.0 M3software. Since SmartPLS is an model estimation and SEM analysis programme, the estimation process used two steps to evaluate the outer and inner models (Hair, Sarstedt, Hopkins \& Kuppelwieser, 2014). First, the measurement model of the relationships between the indicators and constructs was determined (Roldán \& Sánchez-Franco, 2012). Second, the estimation of the structural model of the relationships was evaluated for different constructs. The following criteria facilitated this assessment: path coefficients $(\beta)$ and their significance levels (Student's $t$ distribution), coefficient of determination $\left(R^{2}\right)$ and cross-validated redundancy $\left(Q^{2}\right)$ (Hair et al., 2014). These steps ensured that we had adequate indicators of constructs before we attempted to reach conclusions 
concerning the relationships included in the inner model (Roldán \& Sánchez-Franco, 2012).

\subsection{Measurement model assessment}

The PLS assessment of the measurement model for reflective indicators was based on individual item reliability, construct reliability, convergent validity (Tenenhaus, Vinzi, Chatelin, \& Lauro, 2005) and discriminant validity (Hair, Sarstedt, Ringle \&
Mena, 2012). Individual item reliability was assessed by analysing the standardised loadings $(\lambda)$ or simple correlations of the indicators with their respective latent variable $(\lambda)$ (Hair et al., 2014). Individual item reliability is considered adequate when an item has a factor loading $(\lambda)$ greater than 0.707 on its respective construct (Carmines \& Zeller, 1979). In the present study, all reflective indicators have loadings above 0.715 (see boldface numbers in Table 1).

Table 1 - Loadings and cross-loadings for measurement model

\begin{tabular}{|c|c|c|c|}
\hline Items & CSR Strategy & Performance & Competitiveness \\
\hline EST01 & 0.832 & 0.390 & 0.325 \\
\hline EST02 & 0.715 & 0.268 & 0.269 \\
\hline EST03 & 0.819 & 0.365 & 0.487 \\
\hline EST04 & 0.763 & 0.242 & 0.338 \\
\hline EST05 & 0.775 & 0.303 & 0.328 \\
\hline EST06 & 0.856 & 0.351 & 0.446 \\
\hline EST07 & 0.875 & 0.403 & 0.444 \\
\hline EST08 & 0.798 & 0.504 & 0.519 \\
\hline EST09 & 0.848 & 0.440 & 0.439 \\
\hline EST10 & 0.845 & 0.540 & 0.567 \\
\hline EST11 & 0.830 & 0.471 & 0.568 \\
\hline EST12 & 0.884 & 0.461 & 0.501 \\
\hline EST13 & 0.904 & 0.544 & 0.558 \\
\hline EST14 & 0.808 & 0.434 & 0.513 \\
\hline PER01 & 0.424 & 0.862 & 0.490 \\
\hline PER02 & 0.305 & 0.797 & 0.566 \\
\hline PER03 & 0.241 & 0.736 & 0.471 \\
\hline PER04 & 0.467 & 0.817 & 0.456 \\
\hline PER05 & 0.483 & 0.775 & 0.799 \\
\hline PER06 & 0.557 & 0.889 & 0.710 \\
\hline PER07 & 0.487 & 0.921 & 0.717 \\
\hline PER08 & 0.469 & 0.904 & 0.633 \\
\hline PER09 & 0.319 & 0.792 & 0.587 \\
\hline COM01 & 0.440 & 0.764 & 0.777 \\
\hline COM02 & 0.546 & 0.635 & 0.794 \\
\hline COM03 & 0.458 & 0.686 & 0.868 \\
\hline COM04 & 0.487 & 0.674 & 0.835 \\
\hline COM05 & 0.432 & 0.555 & 0.769 \\
\hline COM06 & 0.421 & 0.632 & 0.827 \\
\hline COM07 & 0.461 & 0.728 & 0.884 \\
\hline COM08 & 0.393 & 0.678 & 0.849 \\
\hline COM09 & 0.482 & 0.642 & 0.866 \\
\hline COM10 & 0.442 & 0.581 & 0.872 \\
\hline COM11 & 0.428 & 0.487 & 0.806 \\
\hline COM12 & 0.479 & 0.667 & 0.891 \\
\hline COM13 & 0.519 & 0.562 & 0.835 \\
\hline COM14 & 0.396 & 0.444 & 0.735 \\
\hline COM15 & 0.432 & 0.485 & 0.768 \\
\hline COM16 & 0.463 & 0.511 & 0.827 \\
\hline COM17 & 0.633 & 0.655 & 0.884 \\
\hline
\end{tabular}

In measurement models with reflective indicators, construct reliability is usually assessed using composite reliability $\left(\rho_{c}\right)$ (Hair et al., 2014) and Cronbach's a (Castro \& Roldán, 2013) to evaluate the internal consistency of the constructs. Following the guidelines proposed by Nunnally and Bernstein (1994), a value of 0.7 was used as abenchmark for modest reliability applicable to exploratory research. All the constructs presented values above 0.7 , and even the more restrictive threshold of 0.8 was exceeded (Nunnally \& Bernstein, 1994) (see Table 2). To assess convergent validity, we examined the average variance extracted (AVE). AVE values should be greater than 0.50 (Fornell \& Larcker, 1981). 
Table 2: Composite reliability $\left(\rho_{c}\right)$ and convergent and discriminant validity coefficients

\begin{tabular}{|l|c|c|c|c|c|c|}
\hline & $\rho \boldsymbol{c}$ & Cronbach's $\boldsymbol{\alpha}$ & $\boldsymbol{A V E}$ & Competitiveness & CSR Strategy & Performance \\
\hline Competitiveness & 0.974 & 0.972 & 0.689 & $\mathbf{0 . 8 3 0}$ & 0 & 0 \\
\hline CSR Strategy & 0.968 & 0.964 & 0.683 & 0.564 & $\mathbf{0 . 8 2 7}$ & 0 \\
\hline Performance & 0.954 & 0.945 & 0.697 & 0.746 & 0.513 & $\mathbf{0 . 8 3 5}$ \\
\hline
\end{tabular}

Notes: Diagonal elements in bold are the square root of the variance shared between the constructs and their measures (i.e. AVE); off-diagonal elements are the correlations among constructs; for discriminant validity, diagonal elements should be larger than offdiagonal elements.

Source: Authors.

Discriminant validity indicates the extent to which a given construct differs from other constructs. There are two approaches to assessing discriminant validity (Gefen \& Straub, 2005). Fornell and Larcker (1981) suggest the use of the average variance shared between a construct and its measures (i.e. AVE). This measure should be higher than the shared variance between the construct and other constructs in the model. To put this idea into operation, the square root of AVE of each construct should be greater than its correlations with any other construct in the model assessed. In the present study, this condition is satisfied by all constructs in relation to other variables (see Table 2 above).

The second approach suggests that each item should load more highly on its assigned construct than it does on other constructs (Henseler, Ringle \& Sinkovics, 2009). This cross-loading analysis can be performed by calculating the correlations between the construct scores and the standardised data of the indicators. As can be observed in Table 1 above, this condition was satisfied.

\subsection{Structural model assessment}

Once the reliability and validity of the outer model was established, several steps needed to be taken to evaluate the hypothesised relationships within the structural model (Hair et al., 2014). The structural model was assessed basicallyby examining the meaningfulness and significance of the relationships hypothesised between the constructs. The model's quality depended on its ability to predict endogenous constructs. The following criteria was used to facilitate this assessment (Hair et al., 2014): path coefficients ( $\beta$ ) and their significance levels (Student's t distribution), coefficient of determination $\left(R^{2}\right)$ and cross-validated redundancy $\left(Q^{2}\right)$.

First, we tested the significance of all the paths of the structural model. Standardised path coefficients were used to analyse the degree of support for the research hypotheses. Chin, (1998) proposed that this analysis should produce standardised path coefficients with values greater than 0.2 or, more ideally, 0.3 . When the $\beta$ is less than 0.2 , there is no causality, and the hypothesis is rejected. Bootstrapping (i.e. 5,000 resamples) was used to generate standard errors and t-statistics. This enabled us to assess the statistical significance of the path coefficients (Castro \& Roldán, 2013). At the same time, the bootstrapping confidence intervals of standardised regression coefficients were used to accept or reject the hypotheses (see Table 3).

Table 3 - Hypothesis testing

\begin{tabular}{ccccr}
\hline Hypothesis & Relationship & $\boldsymbol{\beta}$ & Standard Error & $\boldsymbol{t}$ - Statistics \\
\hline H1 & CSR Strategy -> Performance & $0.135^{\text {n.s. }}$ & 0.101 & 1.339 \\
H2 & CSR Strategy -> Competitiveness & $0.564^{* * *}$ & 0.090 & 6.291 \\
H3 & Competitiveness -> Performance & $0.669^{* * *}$ & 0.097 & 6.934
\end{tabular}

Notes: $\mathrm{t}(0.05,4999)=1.645158499 ; \mathrm{t}(0.01,4999)=2.327094067 ; \mathrm{t}(0.001,4999)=3.091863446 ;{ }^{*} \mathrm{p}<0.05 ;{ }^{* *} \mathrm{p}<0.01 ;$ $* * * \mathrm{p}<0.001 ; \mathrm{n} . \mathrm{s} .=$ not significant (based on $\mathrm{t}(4999)$, one-tailed test)

Source: Authors.

Second, the goodness of the proposed model was determined by the strength of each structural path. This analysis was done using the $R^{2}$ values (i.e. explained variance) for dependent latent variables. For each path between constructs, the desirable values needed to be at least equal to or higher than 0.1 (Falk \& Miller, 1992). The $R^{2}$ is a measure of the model's predictive accuracy (Hair et al., 2014), and, therefore, $\mathrm{R}^{2}$ values measure the construct variance explained by the model. Values of 0.75 , 0.50 and 0.25 describe substantial, moderate or weak levels, respectively, of predictive accuracy (Hair, Ringle, \& Sarstedt, 2011). As shown in Figure 2, the model has a high predictive power. 
Figure 2: Hypothesis testing

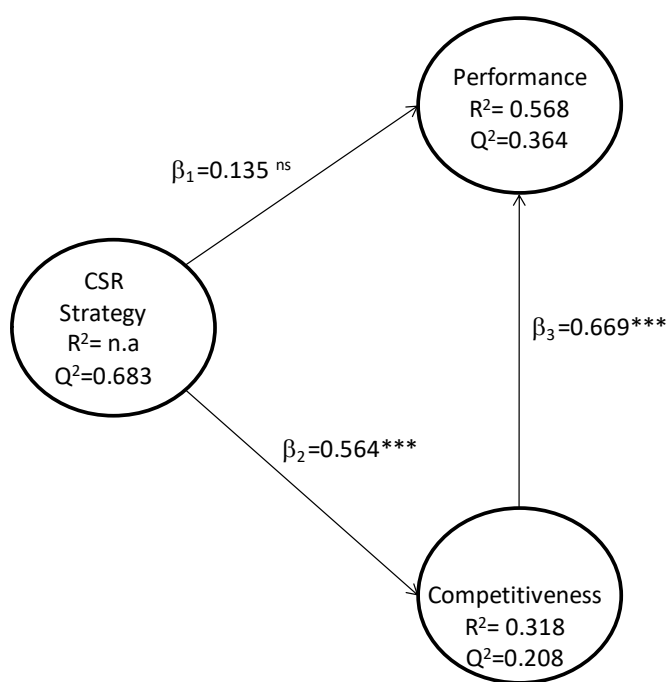

Notes: $\mathrm{t}(0.05,4999)=1.645158499 ; \mathrm{t}(0.01 .4999)=2.327094067 ; \mathrm{t}(0.001,4999)=3.091863446 ; * \mathrm{p}<0.05 ; * * \mathrm{p}<0.01$; $* * * \mathrm{p}<0.001 ; \mathrm{n} . \mathrm{s} .=$ not significant $($ based on $\mathrm{t}(4999)$, one-tailed test); $\mathrm{n} . \mathrm{a} .=$ not available Source: Authors.

Finally, the Stone-Giesser test or cross-validated redundancy index $\left(Q^{2}\right)$ was used to assess the predictive relevance of endogenous constructs within the proposed reflective measurement model (Roldán \& Sánchez-Franco, 2012). This was done to ensure the inner model has predictive relevance (Hair et al., 2014). This test is an indicator of how well observed values are reproduced by the model and its estimated parameters. The cross-validated redundancy index $\left(Q^{2}\right)$ was used with endogenous reflective constructs (Castro \& Roldán, 2013). A Q ${ }^{2}$ greater than 0 implies that the model has predictive relevance, whereas a $Q^{2}$ less than 0 suggests that the model lacks predictive relevance (Castro \& Roldán, 2013). According to these guidelines, the results of the present analysis show that the proposed model has predictive relevance for the constructs because a positive $Q^{2}$ value was obtained (see Figure 2 above).

The results summarised in Figure 2 confirm that the structural model has a satisfactory predictive relevance for the two dependent variables: competitiveness and performance. It is, therefore, possible to state that Hypotheses 2 and 3 are supported by the data. However, the same cannot be said for Hypothesis 1 . The latter hypothesis can only be confirmed by following Gallardo-Vázquez and Sánchez Hernández's (2013) suggestion to take into account the total effects (i.e. direct and indirect), which are shown in Table 4.

Table 4: Total effects

\begin{tabular}{|l|c|c|c|}
\hline Relationships & $\boldsymbol{\beta}$ & Standard Error & $\boldsymbol{t}$-Statistics \\
\hline CSR Strategy -> Performance & $0.513^{* * *}$ & 0.086 & 5.992 \\
\hline CSR Strategy ->Competitiveness & $0.564^{* * *}$ & 0.090 & 6.291 \\
\hline Competitiveness -> Performance & $0.669^{* * *}$ & 0.097 & 6.934 \\
\hline
\end{tabular}

Notes: $\mathrm{t}(0.05,4999)=1.645158499 ; \mathrm{t}(0.01,4999)=2.327094067 ; \mathrm{t}(0.001,4999)=3.091863446 ;{ }^{*} \mathrm{p}<0.05 ; * * \mathrm{p}<0.01$; $* * * \mathrm{p}<0.001 ; \mathrm{n} . \mathrm{s} .=$ not significant (based on $\mathrm{t}(4999)$, one-tailed test)

Source: Authors.

As can be seen in Table 4, the total effect of CSR strategies on performance is greater than its direct effect alone, and the total effect is also significant $(\beta=0.513 ; \mathrm{p} \leq 0.001)$. The total effect is obtained with the following formula: Total effect = Direct effect + Indirect effect (Sarstedt, Ringle, Smith, Reams, \& Hair, 2014).

The results of the analysis of CSR strategies' total effects suggest that competitiveness mediates the relationship between the CSR strategies and performance of technological companies. Thus, we found it worthwhile to test explicitly for this potential mediating effect. To do this, three questions needed to be answered (Hair, Hult, Ringle, \& Sarstedt, 2013):
(1) Is the direct effect between CSR strategies and performance significant when the mediator variable is excluded from the path model?

(2) Is the indirect effect via the mediator variable significant after competitiveness has been included in the path model?

(3) How much of the direct effect is absorbed by the indirect effect via the mediator variable?

To answer the first question, we excluded competitiveness from the path model and ran the bootstrapping routine with the previously described specifications. The results reveal that the direct effect between CSR strategies and performance is 0.524 , 
at a significance level of 0.001 . Answering the second question required re-estimating the full model (i.e. with the mediator included) and testing the indirect effect's significance. The corresponding bootstrapping results indicate that the indirect effect of 0.377 has a significance level of 0.001 (Vinzi, Chin, Henseler, \& Wang, 2010). Finally, we computed the variance accounted for (VAF) by the model (Vinzi et al., 2010). This final analysis produced a VAF value of 0.735 , which, according to (Hair et al., 2013), suggests that competitiveness partially mediates the relationship between CSR strategies and performance.

\section{Conclusions}

The objective of the above data analyses was to determine the impact of CSR strategies on the competitiveness and performance of Spanish technological firms. The results show that these strategies have a significant effect on competitiveness, but the impact of CSR strategies on performanceis not as clear, which is in line with other studies' findings (Muñoz et al., 2015). If the mediating role of competitiveness is considered, CSR has a positive influence on performance. These results, therefore, highlight the need to recognise that CSR strategies area driver of performance through competitiveness and that CSR has an important role in technology companies.

Our study provides empirical proof that CSR strategies positively influence the competitiveness of technology companies. Competitiveness has a direct positive effect on performance and ensures CSR strategies have an influence through competitiveness on performance, so adopting CSR strategies can be said to have positive impacts for technology companies in relation to both performance and competitiveness. The implementation of socially responsible strategies not only translates into an ethical or moral positioning by organisations but also into the generation of intangibles of high strategic value, such as competitiveness and performance.

This validation of the proposed model may help technological entrepreneurs and managers to understand why they need to pay attention to CSR issues and what they should expect fromany effort they make to developtheir organisations' environmental and social strategies - beyond purely economic benefits. From a practical point of view, technology companies can use the results of this study as empirical support for the benefits of enhancing the integration of CSR into corporate strategies and of taking advantage of management synergies created between performance and competitiveness. CSR strategies' implementation in technological companies, as demonstrated by the present research, has a direct relationship with competitiveness, which mediatesCSR strategies' positive influence on performance -a finding that is in line with other studies (Chang, 2009).

As in all empirical studies, the present study's limitations must be identified and considered when seeking to interpretits results and draw conclusions. First, the sample was restricted to companies in Spain, which could be seen as a restriction on the generalisability of the results. However, our findings are consistent with the literature and the results of previous studies from non-Spanish samples (Hur et al., 2014; Turyakira et al.,
2014), which clearly supports the validity of the present results for companies outside Spain. Second, the technique used to validate the proposed model - structural equation modelling -is a limitation because it assumes the linearity of the relationships between the latent variables (Castro \& Roldán, 2013). Last, technology companies are dynamic organisations that change over time. Consequently, future research needs to assess the proposed constructs repeatedly over time, taking into account changing dynamics to reconfigure the different dimensions of CSR.

Despite these limitations, the present research can be seen as making a unique contribution to the literature because this study represents a starting point for investigations into the impact of CSR on technology companies and, therefore, covers an identified gap in this field. Moreover, this study's findings supplement previous studies that have examined CSR and its integration into companies' strategies, since the present research analysed this relationship in terms of not only its direct effectbut also its indirect influence through competitiveness.

\section{References}

Apospori, E., Zografos, K. G., \& Magrizos, S. (2012). SME corporate social responsibility and competitiveness: a literature review. International Journal of Technology Management, 58(1/2), 10-31. https://doi.org/10.1504/IJTM.2012.045786

Bagozzi, R. P., \& Yi, Y. (2011). Specification, evaluation, and interpretation of structural equation models. Journal of the Academy of Marketing Science, 40(1), 8-34. https://doi.org/10.1007/s11747-011-0278-x

Battaglia, M., Testa, F., Bianchi, L., Iraldo, F., \& Frey, M. (2014). Corporate Social Responsibility and Competitiveness within SMEs of the Fashion Industry: Evidence from Italy and France. Sustainability, 6(2), 872-893. https://doi.org/10.3390/su6020872

Bocquet, R., Le Bas, C., Mothe, C., \& Poussing, N. (2013). Are firms with different CSR profiles equally innovative? Empirical analysis with survey data. European Management Journal, 31(6), 642-654. https://doi.org/10.1016/j.emj.2012.07.001

Boulouta, I., \& Pitelis, C. N. (2014). Who Needs CSR? The Impact of Corporate Social Responsibility on National Competitiveness. Journal of Business Ethics, 119(3), 349-364. https://doi.org/10.1007/s10551-013-1633-2

Carmines, E. G., \& Zeller, R. A. (1979). Reliability and Validity Assessment. SAGE Publications.

Castro, I., \& Roldán, J. L. (2013). A mediation model between dimensions of social capital. International Business Review, 22(6), 1034-1050. https://doi.org/10.1016/j.ibusrev.2013.02.004

Chang, C.-P. (2009). The relationships among corporate social responsibility, corporate image and economic performance of hightech industries in Taiwan. Quality and Quantity, 43(3), 417-429. https://doi.org/10.1007/s11135-007-9117-z

Chin, W. W. (1998). Commentary: Issues and opinion on structural equation modeling. JSTOR. Recuperado a partir de http://www.jstor.org/stable/249674

Dahlsrud, A. (2008). How corporate social responsibility is defined: an analysis of 37 definitions. Corporate Social Responsibility and Environmental Management, 15(1), 1-13. https://doi.org/10.1002/csr.132

Falk, R. F., \& Miller, N. B. (1992). A Primer for Soft Modeling (1st edition). Akron, Ohio: Univ of Akron Pr. 
Fornell, C., \& Larcker, D. (1981). Evaluating Structural Equation Models with Unobservable Variables and Measurement Error. Journal of Marketing Research, 18(1), 39-50. https://doi.org/10.2307/3151312

Gallardo-Vázquez, D., \& Sánchez-Hernández, M. I. (2013). Análisis de la incidencia de la responsabilidad social empresarial en el éxito competitivo de las microempresas y el papel de la innovación. Universia Business Review, (38), 14-31.

Gallardo-Vázquez, D., \& Sánchez-Hernández, M. I. (2014). Measuring Corporate Social Responsibility for competitive success at a regional level. Journal of Cleaner Production, 72, 14-22. https://doi.org/10.1016/j.jclepro.2014.02.051

Garcia-Castro, R., Ariño, M. A., \& Canela, M. A. (2009). Does Social Performance Really Lead to Financial Performance? Accounting for Endogeneity. Journal of Business Ethics, 92(1), 107-126. https://doi.org/10.1007/s10551-009-0143-8

Gefen, D., \& Straub, D. (2005). A practical guide to factorial validity using PLS-Graph: Tutorial and annotated example. Communications of the Association for Information systems, 16(1), 5.

Gjølberg, M. (2009). Measuring the immeasurable?: Constructing an index of CSR practices and CSR performance in 20 countries. Scandinavian Journal of Management, 25(1), 10-22. https://doi.org/10.1016/j.scaman.2008.10.003

Goldsmith, S. (2010). The Power of Social Innovation: How Civic Entrepreneurs Ignite Community Networks for Good. John Wiley \& Sons.

Hair, J. F., Ringle, C. M., \& Sarstedt, M. (2011). PLS-SEM: Indeed a Silver Bullet. Journal of Marketing Theory and Practice, 19(2), 139-152. https://doi.org/10.2753/MTP1069-6679190202

Hair, J. F., Sarstedt, M., Ringle, C. M., \& Mena, J. A. (2012). An assessment of the use of partial least squares structural equation modeling in marketing research. Journal of the Academy of Marketing Science, 4O(3), 414-433. https://doi.org/10.1007/s11747-011-0261-6

Hair Jr, J. F., Hult, G. T. M., Ringle, C., \& Sarstedt, M. (2013). A Primer on Partial Least Squares Structural Equation Modeling (PLS-SEM). SAGE Publications.

Hair Jr, J. F., Sarstedt, M., Hopkins, L., \& Kuppelwieser, V. G. (2014) Partial least squares structural equation modeling (PLS-SEM): An emerging tool in business research. European Business Review, 26(2), 106-121. https://doi.org/10.1108/EBR-10-2013-0128

Hammann, E.-M., Habisch, A., \& Pechlaner, H. (2009). Values that create value: socially responsible business practices in SMEs - empirical evidence from German companies. Business Ethics: A European Review, 18(1), 37-51. https://doi.org/10.1111/j.14678608.2009.01547.x

Henseler, J., Ringle, C. M., \& Sinkovics, R. R. (2009). The use of partial least squares path modeling in international marketing. En New Challenges to International Marketing (Vol. 20, pp. 277-319). Emerald Group Publishing Limited. Recuperado a partir de http://www.emeraldinsight.com/doi/abs/10.1108/S14747979(2009)0000020014

Herrera, J., Larrán, M., \& Martínez-Martínez, D. (2013). Relación entre responsabilidad social y performance en las pequeñas y medianas empresas: Revisión bibliográfica. Cuadernos de Gestión, 13(2), 3965. https://doi.org/10.5295/cdg.120360jh

Hillenbrand, C., Money, K., \& Ghobadian, A. (2013). Unpacking the Mechanism by which Corporate Responsibility Impacts Stakeholder Relationships. British Journal of Management, 24(1), 127-146. https://doi.org/10.1111/j.1467-8551.2011.00794.x

Hur, W.-M., Kim, H., \& Woo, J. (2014). How CSR Leads to Corporate Brand Equity: Mediating Mechanisms of Corporate Brand Credibility and Reputation. Journal of Business Ethics, 125(1), 75-86. https://doi.org/10.1007/s10551-013-1910-0
Janssen, C., Sen, S., \& Bhattacharya, C. (2015). Corporate crises in the age of corporate social responsibility. Business Horizons, 58(2), 183-192. https://doi.org/10.1016/j.bushor.2014.11.002

Jimenez-Zarco, A. I., Cerdan-Chiscano, M., \& Torrent-Sellens, J. (2013). Challenges and Opportunities in the Management of Science Parks: design of a tool based on the analysis of resident companies. Review of Business Management. https://doi.org/10.7819/rbgn.v15i48.1503

Ketchen, D. J., Combs, J. G., Russell, C. J., Shook, C., Dean, M. A., Runge, J., ... Lamoureux, S. (1997). Organizational Configurations And Performance: A Meta-Analysis. Academy of Management Journal, 4O(1), 223-240. https://doi.org/10.2307/257028

Lee, M.-D. P. (2008). A review of the theories of corporate social responsibility: Its evolutionary path and the road ahead. International Journal of Management Reviews, 10(1), 53-73. https://doi.org/10.1111/j.1468-2370.2007.00226.x

Lo, S.-F. (2010). Performance evaluation for sustainable business: a profitability and marketability framework. Corporate Social Responsibility and Environmental Management, 17(6), 311-319. https://doi.org/10.1002/csr.214

Marín, L., Rubio, A., \& de Maya, S. R. (2012). Competitiveness as a Strategic Outcome of Corporate Social Responsibility: Competitiveness and CSR. Corporate Social Responsibility and Environmental Management, 19(6), 364-376. https://doi.org/10.1002/csr.1288

Melé, D., Argandoña, A., \& Sanchez-Runde, C. (2011). Facing the Crisis: Toward a New Humanistic Synthesis for Business. Journal of Business Ethics, 99(1), 1-4. https://doi.org/10.1007/s10551-011-0743-y

Mendoza, S., de Nieves, C., \& Briones, A. J. (2010). Capacidades Empresariales en Responsabilidad Social y Cooperación en los Agronegocios de la Región de Murcia.

Miquel, S., Bigné, E., Cuenca, A. C., Miquel, M. J., \& Lévy, J. . (1997). Investigación de mercados. Madrid: McGraw-Hill.

Muñoz, R. M., Pablo, J. D. S. de, \& Peña, I. (2015). Linking corporate social responsibility and financial performance in Spanish firms. European Journal of International Management, 9(3), 368-383. https://doi.org/10.1504/EJIM.2015.069133

Nunnally, J. C., \& Bernstein, I. H. (1994). Psychometric Theory (3rd edition). New York: McGraw-Hill.

Pérez, A., \& Bosque, I. R. del. (2012). Measuring CSR Image: Three Studies to Develop and to Validate a Reliable Measurement Tool. Journal of Business Ethics, 118(2), 265-286. https://doi.org/10.1007/s10551012-1588-8

Pérez-Ruiz, A., \& Rodríguez-del-Bosque, I. (2012). La imagen de Responsabilidad Social Corporativa en un contexto de crisis económica: El caso del sector financiero en España. Universia Business Review, (33), 14-29.

Porter, M. E., \& Kramer, M. R. (2006). Strategy and Society: The Link between Competitive Advantage and Corporate Social Responsibility. Recuperado a partir de http://www.hbs.edu/faculty/Pages/item.aspx?num=23102

Prado-Lorenzo, J. M., Gallego-Álvarez, I., García-Sánchez, I.-M., \& Rodríguez-Domínguez, L. (2008). Social responsibility in Spain: Practices and motivations in firms. Management Decision, 46(8), 1247-1271. https://doi.org/10.1108/00251740810901417

Prajogo, D., Tang, A. K. Y., \& Lai, K. (2012). Do firms get what they want from ISO 14001 adoption?: an Australian perspective. Journal of Cleaner Production, 33, 117-126. https://doi.org/10.1016/j.jclepro.2012.04.019

Ramos, M. I. G., Manzanares, M. J. D., \& Gómez, F. G. (2014). El efecto del papel mediador de la reputación corporativa en la relación entre 
la rsc y los resultados económicos. Revista de Estudios Empresariales. Segunda Época, (1). Recuperado a partir de http://revistaselectronicas.ujaen.es/index.php/REE/article/view/13 78

Reinartz, W., Haenlein, M., \& Henseler, J. (2009). An empirical comparison of the efficacy of covariance-based and variance-based SEM. International Journal of Research in Marketing, 26(4), 332-344. https://doi.org/10.1016/j.jiresmar.2009.08.001

Rives, L. M., \& Bañón, A. R. (2008). La responsabilidad social corporativa como determinante del éxito competitivo: un análisis empírico. Revista europea de dirección y economía de la empresa, 17(3), 2742.

Roldán, J. L., \& Sánchez-Franco, M. J. (2012). Variance-Based Structura Equation Modeling: Guidelines for Using Partial Least Squares. Research methodologies, innovations and philosophies in software systems engineering and information systems, 193.

Sarstedt, M., Ringle, C. M., Smith, D., Reams, R., \& Hair, J. F. (2014). Partial least squares structural equation modeling (PLS-SEM): A useful tool for family business researchers. Journal of Family Business Strategy, 5(1), 105-115 https://doi.org/10.1016/j.jfbs.2014.01.002

Spanos, Y. E., \& Lioukas, S. (2001). An examination into the causal logic of rent generation: contrasting Porter's competitive strategy framework and the resource-based perspective. Strategic $\begin{array}{lll}\text { Management Journal, 22(10), 907-934. } & \end{array}$ https://doi.org/10.1002/smj.174

Suñe, A., Bravo, E., Mundet, J., \& Herrera, L. (2012). Buenas prácticas de innovación: un estudio exploratorio de empresas tecnológicas en el sector audiovisual español. Investigaciones Europeas de Dirección y Economía de la Empresa, 18(2), 139-147.

Tenenhaus, M., Vinzi, V. E., Chatelin, Y. M., \& Lauro, C. (2005). PLS path modeling. Computational Statistics \& Data Analysis, 48(1), 159-205. https://doi.org/10.1016/j.csda.2004.03.005

Turyakira, P., Venter, E., \& Smith, E. (2014). The impact of corporate social responsibility factors on the competitiveness of small and medium-sized enterprises. South African Journal of Economic and Management Sciences, 17(2), 157-172.

Venter, E., Turyakira, P., \& Smith, E. E. (2014). The influence of potential outcomes of corporate social responsibility engagement factors on SME competitiveness. South African Journal of Business Management, 45(4), 33-43.

Vidales, K. B. V., \& Ortiz, D. A. A. (2014). Responsabilidad social de las empresas agrícolas y agroindustriales aguacateras de Uruapan, Michoacán, y sus implicaciones en la competitividad. Contaduría y Administración, 59(4), 223-251.

Vilanova, M., Lozano, J. M., \& Arenas, D. (2009). Exploring the Nature of the Relationship Between CSR and Competitiveness. Journal of Business Ethics, 87(S1), 57-69. https://doi.org/10.1007/s10551-0089812-2

Vinzi, V. E., Chin, W. W., Henseler, J., \& Wang, H. (2010). Handbook of Partial Least Squares: Concepts, Methods and Applications. Springer Science \& Business Media.

Wang, D. H.-M., Chen, P.-H., Yu, T. H.-K., \& Hsiao, C.-Y. (2015). The effects of corporate social responsibility on brand equity and firm performance. Journal of Business Research, 68(11), 2232-2236. https://doi.org/10.1016/j.jbusres.2015.06.003
Received: 15 February 2017

Revisions required: 10 April 2017

Accepted: 23 July 2017 